\title{
ESKİ TÜRK TARİHI ARAŞTIRMALARININ İKİ ÖNCÜ İSMI: MUSTAFA CELALEDDİN PAŞA VE DAVID LÉON CAHUN
}

\author{
TWO LEADING FIGURES OF THE ANCIENT TURKISH \\ HISTORIOGRAPHY: MUSTAFA CELALEDDIN PASHA- DAVID \\ LÉON CAHUN
}

Yusuf $A K B A B A^{*}$

\begin{abstract}
$\ddot{O} z$
Avrupa'da başlayan bir süreç ile ağırlık kazanan Eski Türk tarihçiliği, Türkiye'de iç ve dış etkenlerle çalışılmaya başlanmıştır. Değgişen tarihçilik anlayışının bu durumda etkisi büyüktür. Avrupa'da, seküler ve kendi içinde tutarlı tarih anlayışı, 18. yüzyılın sonlarına doğru yaygınlaşmış ve 19. yüzyılda da etkisini devam ettirmiştir. Eski Türk tarihçiliğinin başlangıcında oldukça mühim rol oynayan iki isim, Mustafa Celaleddin Paşa ve Léon Cahun da bu süreçten etkilenmiştir. Dönemin bu iki ismi üzerine Türkiye'de bu bă̆lamda çok az çalışma yapılmıştır. Ancak çalışmada da ortaya konulacağı üzere, eski Türk tarihçiliğinin tartışma konuları, alanın ilk eserlerinin ortaya konulduğu zamandan bugüne büyük ölçüde Avrupa'da şekillenmiştir. Türkiye'deki eski Türk tarihi eserleri ise büyük oranda Avrupa'da ortaya atılan tezlere antitez olarak yazılmıştır. Bu durumun örnekleri en erken dönemde dahi görülmektedir. Bu nedenle çalışmada eski Türk tarihçiliğinin ilk eserlerini veren iki önemli isim karşılaştırmalı olarak incelenecektir. İki eserdeki farklı ve benzer yönler, eserlerin hassasiyet noktaları, amaçları ve bu durumdan hareketle bu iki eserin Türk tarihinin antik çă̆ııın modern anlamda yazımına nasıl etki ettiği ortaya konulmaya çalışılacaktır.
\end{abstract}

Anahtar Kelimeler

Mustafa Celaleddin Paşa, Léon Cahun, Tarihyazımı, Eski Türk Tarihi.

\begin{abstract}
The ancient Turkish historiography gained importance in consequence of a process that started in Europe and worked in Turkey as a result of internal and external factors. In Europe, secular and self-consistent understanding of history spread out at the end of the 18th century and continued its influence in the 19th century. Two figures, Mustafa Celaleddin Pasha and Léon Cahun, who took a very important role in the beginning of the ancient Turkish historiography were also influenced by the process. Nevertheless, on these two figures, few works have been done in Turkey in this context. However, as will be demonstrated in the study, the debates of the ancient Turkish historiography have been largely shaped in Europe since the first works of the ancient Turkish history were put forward. Works written about the ancient Turkish history in Turkey are substantially antithesis of the theses
\end{abstract}

Arş. Gör., Eskişehir Osmangazi Üniversitesi, yakbaba@ogu.edu.tr 
set forth in Europe. Examples of this situation could be seen in the earliest period of the ancient Turkish historiography. For this reason, two prominent names that gave the initial works of ancient Turkish historiography will be examined. The different and similar aspects, apprehensions, and aims of these two works and from this point of view how influenced contemporary historiography of the antiquity of the Turkish history will try to show.

\section{Keywords}

Mustafa Celalettin Pasha, Léon Cahun, Historiography, Ancient Turkish History. 


\section{Giriş}

Avrupa'da Doğu toplumları üzerine araştırmaların çok eskiye gittiği söylenebilir. İlk olarak Antik Yunan devletleri göçebe toplumları tanımaya çalışmışlar ve edindikleri bilgileri aktarmışlardır. Buna ilk örnek olarak Herodotos'un Historiai adlı eseri verilebilir. Herodotos, Sakalar ve İskitler hakkında bilgiler vermiştir. Bölgede bahsedilmeye değecek tek halk olarak İskitleri görmüş ve çok sağlıklı olmamakla birlikte bir takım bilgiler aktarmıştır. Bir başka tarihçi Thukydides de Peloponnesos Savaşları adlı eserinde İskitlerden bahsetmiştir. Ayrıntılı bilgi vermemekle birlikte savaşçılıklarına değinmiştir. İskitler, eski Türk tarihi açısından hala çözülemeyen bir problemdir. İskitlerin kökenleri konusu uzun yıllar tartışmalar yapılmış, Birinci Türk Tarih Kongresi'nde de tartışılmıştır. Günümüzde de bu konu hakkında çok farklı görüşler vardır.

Göçebe kavimlerle ve dolayısıyla Türklerle ilgili dikkat çeken eserler Roma İmparatorluğu döneminde de ortaya konulmuştur. Bunlardan biri, Yaşlı Plinius'un Naturalis Historia adlı eseridir. Yaklaşık olarak M.S. 77-79 yıllarında meydana getirilmiştir. Pek çok konuda bilgi vermekte olan bu eser, ansiklopedi niteliği taşıdığı söylenebilir. Göçebe kavimler hakkında da bilgiler de vermekte olup Türk tarihi açısından ayrıntılı bir şekilde araştırılması gereken bir eserdir. Eserde Azak Denizi'nin kıyısında yaşayan "Iyrcae" adındaki bir halktan bahsedilmektedir (Pliny 1855: 15). Bu halktan Pomponius Mela ise "Iurcæque" olarak bahsetmektedir (Mela, 1843: 70; Bury 2015: 492). Türk adının manası açısından bu yazarların ifadeleri, bazı eski Türk tarihi araştırmacıları tarafından incelenmiştir. Zeki Velidi Togan'ın Umumi Türk Tarihine Giriş (İstanbul, 1946) adlı kitabında ortaya koyduğu görüşlerle ile birlikte Roma İmparatorluğu dönemi eserlerinde geçen adlar yoğun şekilde tartışılmış, ancak bu hususta İbrahim Kafesoğlu'nun görüşleri büyük etki yapmıştır. Kafesoğlu, Türk tarihinin antik çağını araştırma hususunda antik Yunan ve Roma kaynaklarına dayanarak ortaya konulan tezler ile kesin sonuçlara varılamayacağını söylemiştir; diğer bazı tarihçiler de bu kanaattedir. Göçebeler hakkında bilgi veren antikçağ eserlerinden bir diğeri ise Ammianus Marcellinus'un Res Gestae adlı kitabıdır. Kitapta Hunlar hakkında da bilgiler vermektedir. Bir Romalının Hunlara bakış açısını yansıtan bu kitap, siyasi ve sosyal yaşam açısından değerli bilgiler vermektedir. Priscus ve Jordanes de eski Türk tarihi açısından önem taşıyan bilgiler vermektedirler. Priscus, Hunlarla yakın temas içerisinde olmuş ve yazdıklarının bir bölümü günümüze ulaşmıştır. Jordanes ise genel olarak göçebe akınları hakkında bilgiler vermektedir. Daha çok Gotlar üzerinde durmuştur. Görüldüğü gibi araştırmaların başlangıcı biraz siyasi çekinceler biraz da "barbarlar"ı tanıma isteği ve merak üzerine olmuştur.

Modern anlamda Türk tarihi çalışmalarına bakılacak olursa 18. yüzyılda Şarkiyatçılık ile yoğunluk kazandığı belirtilebilir. Avrupa'da yoğun olarak ortaya çıkmasındaki nedenler ortaya konulmaya çalışılmalıdır. Tarihçilik açısından etki alanlarına göre tarihsel düşünüş gelenekleri tanımlamak mümkündür. Bu bakımdan İbranice ve Eski Ahit aracıllğıyla eski Yunan ve Roma'dan türeyen Batı geleneği ile 7. yüzyılda meydana gelen İslam ve Çin geleneği geniş bir alanda etki yapmış büyük tesiri olmuştur. Daha dar alanda etki eden tarihsel düşünüş gelenekleri ise Latin Amerika, Afrika ve doğu ve güneydoğu Asya'da gelişenler dâhil olmak üzere geçmiş hakkındaki çeşitli yerel düşünce geleneklerinden oluşur (Woolf, 2005: xxxv). Batı tarzı, uzun müddet dünyanın pek çok yerinde üstünlügünü sürdürmüştür. Batının akademik tarih pratiğinin küresel olarak üstünlük sağlamasının bir sonucu, tarihyazımının da "galibin 
yazdığı" haline gelmesidir. Genel olarak Avrupalıların, daraltılacak olursa Şarkiyatçıların bakış açları, Doğu'ya doğrudan müdahale etmelerinden sonra değişim geçirmiştir (Freitag 1997: 610). Ancak 19. yüzyılda, lengüistik zorlukların da bir sonucu olarak, Batı́da diğer tarihyazımı geleneklerine değinilmemiştir.

$\mathrm{Bu}$ tutum 20. yüzyılda tartışılmaya başlanan modern metodun yükselişine zemin hazırlamıştır. Bu dönemde tarihin bir davranış ve ahlak rehberi olmaktan çok bir süreç ve aynı zamanda bu sürecin tutarlı bir hikâyesi olduğu fikri hâkim olmuştur. Dolayısıyla Hegel'in büyük etkisi vardır. Eski Türk tarihçiliğinin Türkiye'de ortaya çıkışı, Türkiye'de tarihin faydalı bir davranış ve ahlak rehberi olarak görüldügüünü gösterirken, Avrupa'da ortaya çıkış şekli dikkate alındığında tarih sürecinin hikâyesini tutarlı bir şekilde yazma amacı görülmektedir. Sürekli ilerleyen bir tarih düşüncesi Hristiyan düşüncesinde de İslam düşüncesinde de her dönemde mevcuttu. Ancak bu düşünce seküler bir anlam ifade etmiyordu. Bu nedenle, mevcut tutarlı açıklama biçimi de çıkarlara uygun düşecek şekilde ayarlanmalıydı. Irkî vasıflara değinen araştırmalar da bunu göstermektedir. Ancak eskiye nazaran daha sonraki araştırmalarda, yalnızca batı dışındaki tarihyazımına da önem verilmekle kalınmamıştır. Bunların metodolojik olarak aydınlanma yaşaması gereken basit ve aşağı türler olduğu iddiası da bırakılmaya başlanmıştır. Tüm bu süreç doğal olarak, eski Türk tarihi araştırmalarının başlangıcında ve ele alınış şeklinde de büyük rol oynamıştır.

Önemli isimler arasında ilk olarak Joseph de Guignes'ten (1721-1800) bahsedilebilir. Guignes, Histoire generale des Huns des Mongoles des Turcs el des autres Tartares occidentaux adlı bir eser meydana getirmiştir. Eser Hüseyin Cahit Yalçın tarafından Türkçeye çevrilmiş ve 1923 yılında İstanbul'da Tanin Matbaası tarafından 8 cilt halinde yayımlanmıştır. Türk tarihçileri tarafından da kabul edilen önemli bir görüşü ortaya atarak büyük bir etki yapmıştır. Bu görüş, Çin kaynaklarında geçen Hiung-nu halkının Avrupa'daki Hunlarla aynı halk olduğu görüşüdür.

Guignes'in bu teorisi Edward Gibbon (1737-1794) tarafından da ele alınmış ve böylece daha da yaygınlık kazanmıştır. Gibbon, The History of the Decline and Fall of the Roman Empire (Londra, 1776) adlı eserinde Hunlar ve Attila'dan bahsetmiş, Hunların Avrupa'da terör estirdiğine değinmiş ve Hunların Türk halkı olduğunu belirtmiş ve Hiong-nu kökenine önem vermiştir. Bu teoriler Türkiye'deki eski Türk tarihçiliği üzerinde derin bir etki yaratmıştır. Hiung-nu - Hun ilişkisi teorisi de büyük ölçüde savunulmuştur.

Fransız Sinolog Edouard Chavannes (1865-1918) de neredeyse aynı tarihlerde eserler vermiştir. 1889-1893 yılları arasında Çin'de bulunmuş ve araştırmalar yapmıştır. Ayrıca Budizm, Nesturilik, Konfüçyüsizm, Taoizm gibi dinler üzerine de çalışmıştır. Bunun yanı sıra büyük başarılarından biri de Türkistan'da bulunan, tahta üzerine yazılmış ticaret vb. işlerle ilgili belgeleri çözmesi ve çevirmesi olmuştur (Laufer 1918: 203). 1903 yılında ise ünlü eseri Documents Sur Les Tou-kiue Occidentaux (St. Petersburg, 1903) adlı eserini tamamlamıştır. Bu eser Türk kavimleri hakkındaki belgeleri aktarması bakımından büyük önem taşımaktadır. Günümüze kadar bu belgeler kullanılagelmiştir. Ancak yine de zaman zaman Türkler hakkındaki bazı ifadeleri önyargılı bulunarak eleştirilmiştir. Örneğin Mehmed Fuad Köprülü Chavannes'ın Türk sanatı ile ilgili görüşlerini "garip" bulmakta ve eleştirmektedir (Köprülü 2008: 97).

20. yüzyılın başlarında önemli araştırmalar meydana getiren diğer isimler ise, Macar Türkolog Gyula Németh (1890-1976), Lászlő Rásonyi (1899-1984) ve Danimarkalı dilbilimci Vilhelm Thomsen'dir (1842-1927). Nemeth, Hunlar ile ilgili araştırmalar yapmış ve Attila'nın hayatını kaleme almıştır. 1930 yılında Türk Filoloji Enstitüsü'nü kuran Nemeth, Budapeşte 
Üniversitesi'nin rektörlüğünü de yapmıştır (Yüce 1979: 231). 1957 yılında Türk Dil Kurumu onursal üyeliğine seçilmiştir. Nemeth eski Türk tarihinin başlangıcı, eski çağ üzerine fikirler ortaya atmış ve çalışmalar yapmıştır.

Macar Türkolog, Laszlo Rasonyi eski Türk kavimleri üzerine çalışmış ve 1933-1934 yıllarında İstanbul Üniversitesi'nde de görev yapmıştır. Ortaçağ Macar tarihini anlayabilmek adına Türk kavimlerini ve yer adlarını incelemeyi amaçlamıştır. Onun yer adları (onomastik) çalışmaları Türk tarihi bakımından öncü niteliktedir. Ankara Üniversitesi Hungaroloji kürsüsünde Profesörlük görevi yürüten Rasonyi, Türk Tarih Kurumu ve Türk Dil Kurumu'nun da şeref üyesi olmuştur.

Danimarkalı dilbilimci ve Türkolog Vilhelm Thomsen ise 1859 yılında kısa bir süre teoloji çalıştıktan sonra filolojiye yönelmiş ve bu alanda çalışmalarını sürdürmüştür (Konow 1927: 929). 1893 yılında Orhun Yazıtlarını çözerek eski Türk tarihi alanında çığır açmıştır. Çözümlemelerini Dechiffrement des Inscriptions de I'Orkhon et de I'Ienissei: Notice Preliminare (Helsinki, 1896) adıyla aynı yıl yayınlamıştır.

Avrupa'da yapılan çalışmalar kadar Rusya'da yapılan çalışmalar da Türkiye'deki araştırmaları etkilemiştir. Bunun için Rusların Türkler hakkındaki ilk araştırmalarına ve eski Türk tarihi hakkında ilk dönemde neler yazdıklarına değinmek gerekir. Rusya'daki ilk araştırmaların I. Petro döneminde, Kazan'ın 1552'de Rusya'nın eline geçmesiyle başladığ 1 söylenebilir. I. Petro dönemindeki ilk araştırmalar daha çok seyahatnameler ile olmuştur. Bunun yanı sıra dil üzerine de araştırmalar yapılmıştır. Dolayısıyla Türkistan politikası bağlamında yapılan bu çalışmalar ile Türkoloji'nin bir devlet politikası olarak başladığı ifade edilebilir.

Eski Türk tarihi açısından şüphesiz Rus kâşif ve arkeolog Nikolay Mihayloviç Yadrintsev (1842-1894) mühim bir isimdir. Yadrintsev, Moğolistan'da, Uygur Kağanlığı'nın başkentinde araştırmalarda bulunmuş ve kazılar yapmıştır. Onun en önemli katkısı önce Kül Tigin ardından da Bilge Kağan Yazıtı'nı bulmasıdır. Ancak bu yazıtları okuyan Danimarkalı Vilhelm Thomsen olmuştur (1893).

Bu bağlamda öncü isimlerden biri de Alman asıllı Rus Türkolog Vasiliy Vasiliyeviç Radloff (1837-1918), dil üzerine çalışmalar yapmış, Moğolca ve Türkçeyi incelemiş ve sözlükler meydana getirmiştir. O filoloji çalışmalarının yanında, tarih ve kültür alanında da araştırmalarda bulunmuştur. Ayrıca Radloff, Orhun yazıtlarını çözmek için Thomsen ile yarış içinde olsa da Thomsen yazıtları Radloff'tan önce çözmeyi başarmıştır. Neticede Wilhelm Radloff dil ve kültür açısından eski Türk tarihinde oldukça etkili olmuş ve Türk tarihçileri etkilemiştir. Eserlerinden günümüzde hala yararlanılmaktadır.

Ruslar tarafından yapılan eski Türk tarihi araştırmalarına bakıldı̆̆ında Wilhelm Barthold'un (1869-1930) da alanında tüm dünyada ses getirdiği görülmektedir. Barthold 1926'da İstanbul Üniversitesi'nde Orta Asya tarihi hakkında verdiği konferanslar bir kitap haline getirilmiş ve Orta Asya Türk Tarihi Hakkında Dersler (İstanbul, 1927) adıyla yayınlanmıştır. Barthold, ayrıca bu konuda çok sayıda makale de kaleme almış, eski Türk tarihi ile ilgili bilgi verirken hem ana kaynakları değerlendirmiş hem de yeni eserlere ve bulgulara önem vermiştir. Hala eski Türk tarihi alanında başlıca başvuru kaynaklarından biridir. İslam Ansiklopedisi'ndeki 247 makalesi dâhil toplamda 670 eseri vardır (Bregel 1988: 830-832). Eserleri Sobranie Soçineniy (Moskova, 1963-1977) adı altında toplanmış ve 9 cilt halinde yayımlanmıştır.

Dönemin eski Türk tarihi açısından öneme haiz iki entelektüeli de Lehistan asıllı Mustafa Celaleddin Paşa (Konstanty Borzecki) ve Fransız yazar Léon Cahun'dur. Yazdıkları eserler 
Türkiye'deki eski Türk tarihçiliğinin izlediği yön, tartışmalı konuları üzerinde oldukça etkili olmuştur. Ancak Eski Türk tarihçiliğinin izlediği seyri etkileyen bu iki yazarın, eserlerini meydana getirirken güttüğü kaygılar çeşitli iç ve dış etkenlere göre farklılaşmaktadır. Bu nedenle iki yazarın da hayatı, siyasi ve sosyal çevresi ve bu bağlamda eserleri karşılaştırılarak incelenmelidir. Zira "Dışsal ve içsel girişimler birbirini dışlamaz, tamamlar." (Copeaux 2006: 9) Tarihçilik için de bu durum geçerlidir. Eski Türk tarihçiliğinin Türkiye'deki seyrini etkileyen bahis mevzuu iki yazarın eserlerinde ortaya atılan iddialar da hem içsel hem de dışsal etkiler açıdan incelenecek ve Türkiye'deki eski Türk tarihçiliğinde ne ölçüde, hangi konularda etkili olduğu ortaya konulacaktır.

\section{Mühim Bir Safhanın Öncüleri}

Çalışmanın konusunu oluşturan Léon Cahun ve Mustafa Celaleddin Paşa, 18. yüzyılın sonlarına doğru yaygınlaşan ve 19. yüzyılda da etkisini devam ettiren seküler ve kendi içinde tutarlı tarih anlayışından etkilemiştir. Bu dönemde insanlık tarihi bir bütün olarak düşünülmüş ve dinî hassasiyetlerden uzak açıklamalar getirilmeye çalışılmıştır. Ancak bir ayrım yapma gerekliliği de hissedilmiştir. Bu nedenle ilk ayrım uygar-ilkel ayrımı olmuştur. Örneğin Ranke, Çin ve Hindistan'ın tarihleri olmadığını ve bu toplumların durgun olduğunu savunmuştur (Iggers 2004: 2-3). Renan, Buckle, Marx ve Weber de batı üstünlügünün altını çizmiştir (Iggers 2004: 3). Dolayısıyla yeni tutarlı açılama bu bağlamda oluşmuştur.. Georg Iggers'ın da ifadesiyle tarih profesyonelleşmiştir. Ulusal tarih oluşturmaya yönelik araştırmalar köken araştırmalarına dönüşmüştür. Bu süreç Türk tarihçilerde de görülmüştür. Sadece Osmanlı coğrafyasında değil Türk dünyasının geri kalanında da bu süreç görülmektedir. Bu durum aynı zamanda milliyetçiliğin tesirini de göstermektedir Örneğin Rusya Müslümanları arasında da teolojik konulara pek ilgi duymayan, seküler anlayışa sahip ve Batı'yı daha iyi tanıyan bir aydın grubu ortaya çıkmıştı (Kanlıdere 2004: 153). Rusya ilim geleneği ve bilgisini Türkiye'ye getiren isimler Türkiye'deki eski Türk tarihi araştırmalarında etkili olmuştur. (Pala 2012: 2459) Yusuf Akçura İstanbul'da Necip Asım, Rıza Tevfik, Veled Çelebi ve Agop Boyacıyan ile birlikte "Türk diye anılan bütün kavimlerin mazi ve haldeki âsar, ef'âl, ahval ve muhitini öğrenmeye ve öğretmeye çalışmak" için Türk Derneği'ni kurmuştur. (Üstel 2004:35) 1904 yılında Kahire'de

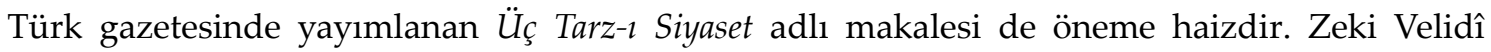
Togan'ın Umumî Türk Tarihine Giriş adlı eseri bugün de örnek verilebilecek bir diğer eserdir. Sadri Maksudî Arsal Türk Tarihi ve Hukuk adlı kitabı ile tanınmıştır. Abdülkadir İnan Tarihte ve Bugün Şamanizm ve Eski Türk Dini Tarihi adlı eserleri ile Türk din tarihi araştırmalarında önemli bir tarihçi olmuştur. Dolayısıyla eski Türk tarihine yönelik ilginin giderek arttığı söylenebilir. Ancak Avrupa'daki süreçten farklı olarak, eski Türk tarihine yönelik ilk adımı Avrupalı şarkiyatçılar atmıştır. Bu durum da daha önce ifade edilen tarihsel düşünüş ile alakalı bir sürecin sonucudur. İlber Ortaylı duruma şu şekilde açıklık getirmektedir: “Türkoloji nedir? Türkiyat veya yeni deyimle Türklük bilgisi. Bu deyim dahi Türkoloji biliminin yaklaşımı ve ismiyle bir ithal olduğunu gösterir." (Ortaylı 2011: 159) Çalışmada, bu süreçte Léon Cahun ve Mustafa Celaleddin Paşa'nın konumları ve yaklaşımları tüm bu gelişmeler ışığında ele alınacaktır. Nitekim E. H. Carr'ın da dediği gibi "Bir kere, tarihin olguları bize hiçbir zaman 'arı' olarak gelmezler, çünkü arı bir biçimde varolmazlar ve varolamazlar. Her zaman kayıt tutanın zihninden kırılarak yansırlar." (Carr 2002: 26)

Konstanty Borzecki 10 Nisan 1826'da doğmuştur. Wincenty Borzecki'nin ikinci çocuğudur (Latka 1987: 15). Ailesi hakkın pek fazla bilgi yoktur. Konstanty Piotrkow'da lise tahsilini yapmıştır. 1844 yılında Varşova'da Güzel Sanatlar Okuluna gitmiş, iki yıl sonra ise okulu terk 
ederek Wloclawek'te bulunan Katolik dini okuluna girmiştir (Latka 1987: 16). Polonya'daki yılları hakkında Jerzy S. Latka, 1848 yılının nisan ayında Prusya'ya ait Wielkopolska'da ihtilal çıtığını ve Konstanty'nin bir arkadaşı ile okuldan kaçarak gizlice bu ihtilale katıldığını ve Konstanty'nin Mayıs ayında onun Prusya'da, kendisinden altı yaş büyük, aynı zamanda ressam olan Polikarp Guminski ile Magdeburg Cezaevi'nde kaldığını öğrendiğini ifade etmektedir (Latka 1987: 16). Daha sonra Borzecki Fransa'ya gitmiş ancak orada uzun süre kalmamıştır. Osmanlı Devleti'nin Polonya'dan gelecek olan muhacirleri kabul edeceğini duyurmasının ardından 1849 yılında, 23 yaşındayken İstanbul'a gelmiştir. Hayatında yeni bir döneme giren Borzecki çok geçmeden Müslüman olmuş, Osmanlı ordusuna katılmış ve kendisine Mustafa Celaleddin ismi verilmiştir. Mustafa Celaleddin Paşa ordudaki görevleri sırasında Osmanlı Devleti'nin nasıl kurtulabileceği üzerine fikir yürütmüştür. Jerzy S. Latka Mustafa Celaleddin Paşa'nın Doğu Acentası'na yazdığı mektubu aktarmaktadır:

1051 yılı Mart ayında müstahkem mevki kurulduğunda Doğu Acentası'na şöyle yazmıştı: “En geç dört ay içinde bütün işlerimi bitirdikten sonra bana vaat edilen altın dağlan Albay ile Harput'a uğrayarak oradan İstanbul'a geleceğim. Bunun gerçekleşip gerçekleşmemesi önemli değildir. Ben kendime olan güvenle zamanımı iyi değerlendirip, her şeyden yararlanmaya çalışacağım, Paşaların vaat ettikleri iyi hal kâğıtları belki bana yardım eder. (Latka 1987: 21)

Yusuf Akçura, Türkçülük adlı eserinde Mustafa Celaleddin Paşa'nın Lehçe dışında iyi derece Latince, Rusça, Fransızca ve Almanca bildiğini belirtmekte ve bunun dişında sanatkârlık kabiliyetinden dolayı mükemmel harita çizdiğini, bu durumunda askeriye de önünü açtığını aktarmaktadır (Akçura 1978: 56). Ayrıca kendi oğluna Latin alfabesi ile Türkçe mektuplar yazmıştır (Gilyazov, 2002: 7). Türk dilinin Arap ve Fars etkisinden arınması gerektiğini savunmuştur (Gilyazov 2002: 7). Mustafa Celaleddin Paşa, Osmanlı ordusuyla Kırım Savaşına da katılmıştır. Osmanlı Devleti'ne uzun yıllar hizmet veren Mustafa Celaleddin Paşa, 1876 yılında Arnavutluk Karadağ- Arnavutluk sınırında vurulmuş ve hayatını kaybetmiş̧tir. Mustafa Celaleddin Paşanın oğlu Enver, babası ile görüşmek için çıktı̆̆ı yolculuk sırasında gördüğü rüyayı damadına şu şekilde aktarmıştır:

Bulunduğum bir hanenin önünde şiddetli bir muharebe oluyor, tüfekler atıliyordu. Pencereden bu hali dehşetle seyrederken arkamdaki kapı birdenbire açıldı, içeri çıplak bir adam girdi, kamından kanlar akıyordu. Yüzüne baktım, pederimdi." Bu rüyanın etkisi ile o derece fenalaşmıştım ki, yataktan aşağı düştüm. Kalkıp yüzümü yıkadım, hava almak için güverteye çıktım, ortalık henüz aydınlanmaya başlamıştı. Rıhtımdan bir sandal hareket etti, vapurun merdivenine yanaştı, içinden bir müvezzi yukarıya çıkarak "Mösyö Enver" diye taharriye (aramaya) başladı. Kendimi bildirdim, elindeki telgrafı aldım, validemdendi. Pederimden alınan emir üzerine acilen gelmem gerektiği bildiriliyordu. Hemen bir kahvehaneye giderek gazeteleri getirttim; ilk okuduğum Şark Havadis-i Telegrafıyesinde: “Dünkü muharebede yaralanan Ferik Mustafa Celaleddin Paşa vefat etti” haberiydi. (Latka 1984: 38-39)

Mustafa Celaleddin Paşa askerlik ve sanat dışında filoloji ve tarih ile de ilgilenmiştir. 1869 yılında adının daha sık anılmasını sağlayacak olan meşhur eseri Les Turcs anciens et modernes adlı eserini tamamlamıştır. Bu eser İstanbul'da Courrier d'Orient gazetesinin matbaasında basılmış ve Sultan Abdülaziz Han'a ithaf olunmuştur. Hem Türkçülük hem de eski Türk tarihçiliği açısından büyük önem taşıyan bu eseri meydana getirme amacını, gözlediklerini yazarak Türkleri korumak, kendisini vatandaşlığa kabul eden bu insanların kaderinin 
iyileştirilmesine tesir etmek ve şarkın gelişmesine yardımcı olmak olarak açıklamaktadır (Akçura 1978: 56). ${ }^{1}$ Türkçülük açısından oldukça önemli olan eser, Cumhuriyetin ilk yıllarında benimsenen resmî tarih görüşüne de büyük etki etmiştir. Zira Mustafa Kemal Atatürk de Mustafa Celaleddin Paşa'nın bu eserini okumuş, hatta üzerine notlar dahi almıştır. Bu bakımdan ne gibi tesirler yaptığının anlaşılabilmesi için eserin dikkatle incelenmesi gerekmektedir.

Mustafa Celaleddin Paşa, Türk tarihini alışılmışın dışında ele almış ve Türk tarihinin bütününe nüfuz etmenin önemine dikkat çekmiştir. Ona göre "Bir milleti derinlemesine incelemek için, varoluşunun değişik dönemlerinde gözlemek gerekir; dolayısıyla geçmişinin bilinmesi, bu inceleme için kaçınılmaz bir şarttır" (Mustafa Celaleddin Paşa, 2014: 43). Mustafa Celaleddin Paşa Fransızca yayımlanan ve Türkçeye Eski ve Modern Türkler adıyla çevrilen Les Turcs anciens et modernes (Paris, 1869) adlı eserinde Türk tarihinin antik çağını araştırmıştır. Avrupa'da "profesyonel" tarihçilerin yaptığına benzer şekilde tarihsel süreç yoluyla Osmanlı Devleti'ne meşruiyet sağlamak istemiştir. Ancak onu ayıran, Osmanlı Devleti'nde Türkler adına bunu yapan ilk tarihçilerden biri olmasıdır. Bu nedenle etkisi de büyük olmuştur. Irk konusundaki açıklamaları dahi dönemin tarihçiliğini ne derece iyi takip ettiğinin bir göstergesidir. Mustafa Celaleddin Paşa bahis mevzuu eserinde, Osmanlı Türklerinin dünyanın en büyük ırklarından biri olduğunu savunmaktadır:

Osmanlı Türkleri, Türk Kafkas ırkındandır; yani halen Türkiye'nin Avrupa ve Asya'daki parçalarıyla, Kuzey Buz Denizinden Kazan ve Lena'ya; Kıpçak ve Kırgız steplerine Türkistan ve ya bağımsız Tataristan, Horasan, Med ve Pers ülkelerinin ve Kırım'ın bir kısmı ile Çin'in kuzeyinde, bu ırkın Moğol veya sarı ırkla karışıp kaybolduğu bölgelere kadar yayılan, dünyanın en büyük ırklarından birine aittirler. (Mustafa Celaleddin Paşa, 2014: 43)

Mustafa Celaleddin Paşa'nın tarihçiliğini Osmanlı Devleti içerisinde farklı kılan bir diğer yön kullandığı kaynaklardır. Sadece İslamî kaynakları referans gösteren tarih kitaplarından farklı olarak Yunan ve Roma kaynaklarına başvurmuştur. Dolayısıyla eski Türk tarihçiliği açısından mühim bir katkısı da bu alanın yöntembilimi üzerine olmuştur. Türkistan'da Çarlık Rusya'sının hâkimiyet kurmaya başladığı yıllarda, tarihsel verilere başvurarak Türklerin bölgede çok daha eski olduğunu kanıtlamaya çalışmıştır. Eserinde yaptığı neredeyse tüm açıklamalar bilimsel kaygı dışında siyasî hassasiyet de taşımaktadır. "Türkistan uygarlığının eskiliği hakkında Bailly'nin araştırmalarından çok daha önce; Pline (His. Nat. VI, 7), Pomponius Mela (1,19), Strabon hatta Herodot'un belirttiği gibi, Türklerin şimdiki Türkistan'da çok eskilerden beri yerleşik oldukları kesindir." şeklindeki ifadesinde, antik çă̆ kaynaklarına dayanarak, Türklerin bölgede ne kadar kadim olduğunu açıklamaktadır (Mustafa Celaleddin Paşa, 2014: 44).

Türk tarihini antik çağdan itibaren ele almasının dışında her coğrafyada izlemeye çalışan Mustafa Celaleddin Paşa, Avrupa'da hala tartışılmakta olan bir meseleyi ele almaktadır. Bu mesele Hyung-nular ile Avrupa Hunlarının bağlantılarıdır. Türkiye'de günümüz eski Türk

Yusuf Akçura eserle ilgili olarak şu değerlendirmeyi yapmıştır: “Bizce eserin asıl büyük değeri, Bütün Türklük ve
Türkçülük hakkında Avrupa kaynaklarından alınıp, şöyle böyle Avrupa metodları takip edilerek Osmanlı Türkleri
arasında ilk yazılan eser olmasındandır; bu eserde ilk defa Türk ırkının güç ve genişliğine, bu irkın insanlık
tarihinde oynadığı muazzam role, Türk dilinin diğer dillerin yardımına muhtaç olmayacak derecede zenginliğine,
Türk dilinin başka dillere yaptığı yardımlara, Asya ve Avrupa'da geniş bir sahaya yayılmış olan Türklerin
münasebetlerine, Osmanlı devleti dâhilinde Türklük fikrine değer verilmemekten doğan mahzurlara, Müslüman
olmayan Osmanlı tebâsını ırk ve dil bağlarıyle Türk kitlesine bağlamak gerektiğine dair görüşlere rastlıyoruz. Yani
Türkçülüğün dil, tarih ve siyaset yönlerinden hepsi bu kitapta az çok söz konusu olmuştur.” Bkz. Akçura, a.g.e., s.
54. 
tarihçiliğinde neredeyse bir sonuca varılmış olsa da Avrupa'da bu mesele hala tartışmalıdır. Mustafa Celaleddin Paşanın eserini yazdığı dönemlerde ise bu konu daha keşif dönemindedir. Avrupa'da Türk tarihi içerisinde ele alınıp alınmaması esere göre değişmektedir. Mustafa Celaleddin Paşa'nın bu eserdeki tutumu ise Kavimler Göçü sırasında Türklerin katkısının görülemediği yönündedir. Kendi ifadesiyle "Attila'nın Hunlarının, Çincede Hionglar (Hungares), Türk olduğu varsayımı, tarihçilerin birkaç alıntısıyla yeterince desteklenmiş olmaz" (Mustafa Celaleddin Paşa, 2014: 45). Ancak bu görüşlerinin altında yatan temel etken farklıdır. Her alanda Türklerin kadim oluşunu vurgulayan Mustafa Celaleddin Paşa, Attila ve Hunlarını neden dışladığı sorusu dönem eski Türk tarihçiliğini anlamak açısından önemlidir. Bu sorunun cevabı, Avrupa Hunlarına günümüzdeki bakışla, o dönemdeki bakışın aynı olmayışında aranmalıdır. Daha önce de ifade edildiği üzere, 19. yüzyılda Avrupa'da "profesyonel tarihçilik" yaygınlık kazanmış ve tarihçiler ulusal tarihlerine bütünlük ve tutarlılık sağlamanın dışında uygar oluşu da vurgulamışlardır. Ayrıca 19. yüzyıla ait ideolojiler ve idealler uzak geçmişte de aranmıştır. Avrupa tarihçiliğini yakından takip eden Mustafa Celaleddin Paşa da doğal olarak, uygarlık derecesine göre halkların sınıflandırıldığı ve tarihsel anlatıya bu ölçüde dâhil edildiği bir dönemde Avrupa Hunlarını benimsememiştir:

Ancak itiraf etmek gerekir ki, Avrupa'ya barbar göçleri ve istilaları tarihinde Çin yıllıklarının verdiği ipuçlarında Türklerin katkısını görmek zordur. Attila'nın Hunlarının, Çincede Hionglar (Hung-ares), Türk olduğu varsayımı, tarihçilerin birkaç alıntısıyla yeterince desteklenmiş olmaz... Bizanslı tarihçilerin, dokuzuncu asırdan itibaren Macaristan'a yerleşen Magy-areslerin milliyetleri hakkında çok az bilgileri vardır; bu yüzden Selçuklu Uygurlara veya bugünkü Türklere, sıklıkla Hongres (Macar) veya Hun adı vermektedirler. (Mustafa Celaleddin Paşa, 2014: 45)

Bu bağlamda Moğollara nasıl yaklaşıldığına da bakılabilir. Diğer Avrupa tarihçilerinin yaptığı gibi Mustafa Celaleddin Paşa'nın da Moğollara yaklaşımı olumlu değildir. Ona göre Türkler, Moğollarla karışıp bozulmuştur. Bu hususta bozulma vurgusu dikkat çekicidir. Ancak yine de Türklerin ırksal özellikleriyle ilgili şunları aktarmaktadır: "Bu milliyetlerden Türklerin, en kalabalık, en enerjik ve bazı bölgelerde Moğol ırkıyla karışıp bozulmakla birlikte, sonuçta Kafkas tipine en yakın ırk olduğu bilinmektedir" (Mustafa Celaleddin Paşa, 2014: 45-46). Mustafa Celaleddin Paşa, Hunların Türk olduğunu varsayımına hiç sıcak bakmasa da bölgede kurulmuş bir "Türk İmparatorluğu"nun varlığını kanıtlama çabası içindedir. Osmanlı Devleti'nde milliyetçi ayaklanmaların baş gösterdiği ve Avrupa'da toprak kayıplarının yaşandığı yıllarda dikkati Türklerin Avrupa'daki varlığına toplaması gayet tabiidir. Ancak bunu yaparken dahi Hunların bu imparatorluk içerisindeki konumuna net bir sinır çizer. Avarlar ile Hunları ayn "millet" kabul eden Paul Diacre'ı da eleştirmektedir. Ona göre Avarlar, Hunlar gibi yıkıcı değildir. Çin kaynakların Türk olarak ifade ettiği Sarı Hunların ise "etobur Moğol" ırkları" ile karışarak yozlaştığını ifade eder (Mustafa Celaleddin Paşa, 2014: 46). Burada hem Hunlara hem de Moğollara yönelik olumsuz bir bakış açısı görülmektedir. Dönem Avrupası'nın Moğollara, Hunlara yaklaşımı esere net bir şekilde yansımıştır. Eserindeki bir ifadesinden Hunları neden Türk kabul etmediği daha iyi bir biçimde anlaşılmaktadır:

...Bu nedenle Avrupa'da Avarlar adı altında Hunların artıklarını ve bazı Uygur kabilelerini bir araya getiren bir Türk İmparatorluğunun varlığı, oldukça yeterli tarihi verilere dayanarak, neredeyse kesinleşmektedir. Paul Diacre'ın Gestis Longobardorum adlı tarih kitabında, Avarların Hunların artıklarıyla yaptığı bu ittifak nedeniyle, bu iki halkın aynı millet olduğunu kabul ettiğine inanıyoruz... Zaten Avarlar, Hunlar gibi yıkıcı 
değillerdi. (Mustafa Celaleddin Paşa, 2014: 46)

Bahis mevzuu eserin yazılmasındaki temel itki noktası siyasîdir. Ancak bu durum diğer Avrupalı tarihçiler için de geçerlidir. Nesnellik ve bilimsellik, ideolojik temelli iddiaların ve tarihsel anlatının üzerini örtmeye yarayan kılıflar olabilmiştir. Mustafa Celaleddin Paşa'nın en çok üzerinde durduğu konu ise Türklerin Avrupa'daki varlı̆̆ 1 ve özellikle de Balkanlarda yaşayan halkların aslında Türklerle aynı soydan olduğudur. Bu yaklaşımıyla Cumhuriyetin ilk dönemlerindeki tarih anlayışına dahi büyük tesir yapmıştır. Din temelli ya da Osmanlılığa dayalı bir yaklaşımdan çok ırksal bir açıklamaya girişir. Jasygelerin tarihi ve yaşadığı coğrafyaya dikkat çeker (Mustafa Celaleddin Paşa, 2014: 48-49). Daha önce de ifade edildiği üzere Pomponius Mela ve Yaşlı Plinius, Moesia çevresinde yaşamış olan bu halktan bahsetmiştir. Ancak bu halkların Türk olduğu fikrini, modern Türk tarihçiliğine bakıldığında ilk dile getiren Mustafa Celaleddin Paşa olmuştur. Bu iddia oldukça etkili olmuş ve eski Türk tarihçileri yıllar boyunca, hatta günümüze değin bu konuya kaynak göstermeden değinmişlerdir. Dolayısıyla Mustafa Celaleddin Paşa'nın ana kaynakları inceleyerek ve dönem tarihçiliğine uygun olarak, belirli bir amaç doğrultusunda öne sürdüğü bu iddia, temelsiz ve kaynak gösterilemeden sürdürüldügünden dolayı Türk tarihçiliğinde dezenformasyona yol açmışır.

Bu itibarla, antik kaynaklarda Türk adının varlığını arayan ilk isimlerden biri olan Mustafa Celaleddin Paşanın, antik Yunan ve Roma kaynaklarını okuyan ve iddiasını destekleyen bölümlerden deliller sunabilen önemli bir eski Türk tarihçisi olduğu söylenebilir. Bahsettiği halkın Türklügü ile ilgili olarak Çince isimlerden de örnekler vermiştir. Jasyge adının da Yasssy'dan türediğini, Osmanlı lehçesinde bu kelimeye Yassı-Yassılılar deneceğini savunmaktadır (Mustafa Celaleddin Paşa, 2014: 51). "Jasyge'ler adının, Küçük Asya'da, hatta Rumeli'de, Manastır'da olageldiği gibi, aslında tamamen Türkçe dil yapısıyla oluştuğuna inanıoruz" diyerek bu halkın birçok yerde etkili olduğunu ifade etmektedir (Mustafa Celaleddin Paşa, 2014: 51). Bu doğrultuda Mustafa Celaleddin Paşa, Türklerin Jasygelerden önce başka topluluklarının olduğunu da iddia etmektedir. Ancak göçebe kavimleri tümüyle Türk ilan etmemiştir. Ona göre Türklerin tarihi yeni bir sayfadan vazgeçmek için oldukça görkemli ve yeter derecede hacimlidir (Mustafa Celaleddin Paşa, 2014: 57). Mustafa Celaleddin Paşa eserinde antik kaynaklarından yola çıkarak Türklerin eski çağına yönelik yaptı̆̆ı araştırmaların siyasi nedenini kitabında açık bir şekilde ifade etmiştir. Kökence Türk olduğunu kanıtlamaya çalıştı̆̆ı kabilelerin, çıkarları doğrultusunda isimleri yok ettiklerini, kökenini bilmeyen bir millet algısı ortaya çıktığını savunur. Yapılanları da "bin türlü sahtekârlık" olarak nitelendirmiştir (Mustafa Celaleddin Paşa, 2014: 60). ${ }^{2}$

Sonuç olarak, Türkiye'nin Avrupa parçasında Osmanlı hâkimiyetinin kurulmasıyla, kökence Türk olan bu kabilelerin, isimlerini yok etmekte meşru çıkar gördüklerini belirtmek gerekir; bu durum, kökenini bilmeyen bir milletin olgusunu açıklar. Günümüzde Osmanlı artık din misyonerliği yapmıyor ve son olarak da, birkaç yüz Müslüman ailenin Hristiyanlığa geçişini bile kayıtsızlıkla karşıladığı görüldü. O zaman kan ve ırk bağının, Hristiyan ve Müslüman hepimizi, sağlam ve kuvvetli bir yapıda birleştirmesini reddetmek niye? (Mustafa Celaleddin Paşa, 2014: 59)

Ayrıca Mustafa Celaleddin Paşa Almanca basılmış olan bir kitapta geçen, Slavların kovaladığı Jassygelerin Trakya ve Moesia'ya yerleştiği bilgisinin, Yunanca bir tercümesinde

2 Mustafa Celaleddin Paşa bu konu ile ilgili olarak Valakları örnek vermektedir: “Bununla birlikte, mürekkep yalamış Valaklar için asıl milliyetleri bir sır değildir. Türkiye içlerinde kitaplık kaynaklarından yoksunsam da, elimin altındaki kitaplarla yine de kökenlerinin bilindiği kantlayabilirim. Bu gerçeği bin türlü sahtekârlıkla örtmeye çalışıyorlar." Bk. Mustafa Celaleddin Paşa, a.g.e., s. 60. 
Jassyge kısmının çıkarılmış olmasını eleştirmektedir. Osmanlıların Hristiyan ve Müslüman olarak bolluk içinde, tek vücut ve güçlü olarak birleştirilmesi ve Osmanlı Hristiyanlarının özgürlüklerini sağlamak için ileri sürülen tehlikeli doktrinlerin niteliklerine gözünü açması gerektiğini savunmuştur (Mustafa Celaleddin Paşa, 2014: 67). ${ }^{3}$ Osmanlı Devletinin artık din misyonerliği yapmadığını belirtmesi de ayrıca dikkate değerdir. Mustafa Celaleddin Paşa, kan ve irk bağ ile birleşmeyi teklif etmektedir. Bunun için de tarihsel verileri kullanmak onun için oldukça elverişli olmuştur. Böylece eski Türk tarihçiliğine yeni bir pencere açmış ve Avrupalı tarihçilerin eski Türk tarihine yaklaşımlarından farklı bir yaklaşım geliştirmiştir. Bu yaklaşım siyasi kaygıların temel itki noktası olmasının bir ürünüdür.

Dolayısıyla içsel olarak Osmanlı Devletindeki isyanlar ve milliyetçi hareketler, dışsal olarak da "Hristiyanların özgürlüklerini sağlamak için ileri sürülen doktrinler" etkili olmuştur (Mustafa Celaleddin Paşa, 2014: 67). Ancak bunu yaparken de uygarlık gibi konularda Avrupa tarihçiliğinin etkisinde bir tarihsel yaklaşım ve anlatı ortaya koymuştur. Mustafa Celaleddin Paşa salt dilsel verilere dayalı araştırmaların yanlışlığına da dikkat çekmiştir. Sadece lehçe ölçütlerine bakarak hareket etmenin yanlış olacağını belirtmiştir. Avrupalı tarihçilerin metotları ve yaklaşımlarıyla, onları yakından takip ederek onlara karşı bir tarih eseri meydana getirmiştir. Türk tarihinin antik çağı, medeniyet mensubiyeti ve başlangıcı gibi tartışmaların temelini oluşturan isimlerden biridir. Türkiye'de eski Türk tarihine bakış açısını şekillendiren isimlerin başında geldiği söylenebilir. Kendisinden önceki araştırmalardan farklı olarak Türk tarihinin antik çağını farklı kaynaklar ile bulmaya çalışmıştır. Eski Türk tarihçiliğinde Avrupa'nın tezlerine cevap verme kaygısı gütmeden, pragmatik bir çerçeve ile eski Türk tarihi alanında yeni bir tez ortaya atan belki de tek isim sayılabilir. Ancak tüm bu konuların eski Türk tarihçiliğinin ilk dönemlerinde tam karşı pencereden nasıl görüldüğüne bakmak da zaruridir. Türkiye'deki eski Türk tarihçiliğini derinden etkileyen ancak görüşleri itibariyle başka bir pencereden bakan Léon Cahun bu bakımdan önemli bir isimdir.

23 Haziran 1841 tarihinde doğan David Léon Cahun Yahudi kökenli Fransız bir ailenin çocuğudur. Ailesi askeri görevlerde bulunmasını ve bu alanda ilerlemesini istese de Cahun, coğrafyacı, gezgin ve tarihçi olarak tanınmıştır. Cahun ilk olarak, 1863 yılında Revenue Française adlı eseriyle adından söz ettirmiştir (Singer-Kahn 1902: 492). Ayrıca 1864-1866 yılları arasında Mısır, Kızıldeniz ve Anadolu'yu gezmiştir (Singer-Kahn 1902: 492). 1866 yılında Fransa'ya dönerek La Liberte'de yazarlık yapmış, ancak bu gazete Fransa'da ikinci imparatorluğu destekleyince, bu gazeteden ayrilarak La Reforme ve La Loi'de yazmaya başlamıştır.

Cahun, 1870 yılında Fransa-Prusya savaşına gönüllü olarak katılmıştır (Singer-Kahn 1902: 492). Savaş sonrasında ise tarih araştırmalarına yönelmiş, özellikle de Türk ve Tatar tarihi ile ilgilenmiştir. Cahun 1875 yılında ise Bibliothèque Mazarine'de idarecilik yapmıştır. Bu dönemlerde tarihî romanlar yazmış, antik çağ ve arkeoloji ile de ilgilenmiştir. En ünlü romanlarından biri La Aventures du Capitaine Magon (Paris, 1875) 'dur. Bir yıl sonra ise elde ettiği bilgi birikimiyle, hem Türk milliyetçiliği hem eski Türk tarihçiliği açısından büyük etki yaratacak olan La Banniere Bleue (Paris, 1876) adlı romanını meydana getirmiştir. Hristiyan ve Müslüman gözünden haçlı seferleri ve Moğol saldırıları dönemini anlatan bu eser, Necip Asım tarafından 1912'de Türkçeye çevrilerek Gök Sancak adıyla yayımlanmıştır. Ayrıca Hasan le Janissaire (Paris, 1891) adlı bir eseri de mevcuttur. Bu eser Fransız Akademisi tarafından

3 Slavizm hareketine karşı durmak gerektiğini belirten Mustafa Celaleddin Paşa şunları ifade eder: Slavların birçoğunun bugün Almanca konuştuğu gibi, Moskova Mordvaslarının Slav dilinde, Polonyalıların Rusça; Kozakların Malo-Rus ve Kalmukların Tatarca konuştuğuna bakarak, yanlış olan lehçe kriterleriyle, köle sayınızı arttıramazsınız." Mustafa Celaleddin Paşa, a.g.e., s. 67. 
ödüllendirilmiştir (Singer-Kahn 1902: 492). Ayrıca çeşitli dergilerde çok sayıda makalesi yayımlanmıştır. 1878-1880 yılları arasında Faroe Adaları'ndan Suriye'ye çok çeşitli bölgeleri gezen Cahun, 1879 yılında, yaptığı seyahatleri kaleme aldığı Tour du Monde’yi yayımlatmıştır.

Neredeyse hiç ara vermeden çeşitli alanlarda araştırmalarını sürdüren Cahun, 1890 yılında Sorbonne'da Asya tarihi ve coğrafyası hakkında dersler vermiştir. 1896 yılında ise seyahatler sırasında elde ettiği materyallerden oluşan Introduction a l'historie de l'Asie: Turcs et Mongols des origines a 1405 adlı eserini meydana getirmiştir. Bu eser Türk milliyetçiliği üzerinde etkili olmuş ve Türkiye'de eski Türk tarihi üzerine yapılan araştırmalara ilgiyi artırmıştır. Bu eser, Asya Tarihine Giriş: Türkler ve Moğollar adı ile Türkçeye çevrilmiştir. Türkçeye ilk çevirisini 1899 yılında Necip Asım yapmıştır. 30 Mart 1900 tarihinde Paris'te hayatını kaybeden oryantalist Léon Cahun, Arap tarihi ve Arapları ele alan tarihî romanını tamamlayamamıştır (Singer-Kahn 1902: 493).

Léon Cahun, roman, makale, seyahatname gibi çok çeşitli eserler meydana getirmiş olsa da, eski Türk tarihi açısından en önemlisi Introduction a l'historie de l'Asie: Turcs et Mongols des origines a 1405 adlı eseridir. Zira bu eser Türkçülük-Turancılık fikirleri açısından büyük etki yaratmıştır. Bunun nedeni ise Türk tarihini bütüncül bir şekilde ortaya koyan ve Türk tarihinin Orta Asya safhasını ciddi bir şekilde ele alan ilk eserlerden biri olmasıdır. Dolayısıyla Türkçülük akımının yaygınlaşmaya başladığı ve bu doğrultuda Avrupa'da olduğu gibi köken araştırmalarının hız kazandığı bir dönemde büyük yankı uyandırması gayet tabiidir. Her ne kadar Cemil Meriç, milliyetçilik akımının bu kaynaklardan geldiğini ifade ederek Deguignes'i "Fransız polisi" olarak nitelemiş ve milliyetçilik ile eski Türk tarihinin Léon Cahun, Vambery, Deguignes gibi yazarlardan öğrenilmesini eleştirmiş olsa da, Léon Cahun, eski Türk tarihçiliği açısından dikkatle değerlendirilmesi gereken bir isimdir (Açıkgöz 2005: 109). Introduction a l'historie de l'Asie: Turcs et Mongols des origines a 1405 adlı eseri de bu bağlamda incelenmelidir.

Léon Cahun Introduction a l'historie de l'Asie: Turcs et Mongols des origines a 1405 adl eserinde, Türk tarihinin eski çağını, Türklerin uygarlık ve medeniyet bağlarını açıklamayı amaçlamıştır. Mustafa Celaleddin Paşa'nın titizlikle Moğolları ve hatta Hunları Türk tarihinden dışlamış olmasına karşılık Cahun, Türkler ile Moğollar arasında bir ayrım yapmamaktadır. Türk tarihi ile ilgili tutarlı ve kapsayıcı bir açıklama bulmaya çalışması dikkat çekicidir. Ona göre Türkler ve Moğollar, Pers ve Çin uygarlıkları arasında bir aracıdır. Kalıcı hiçbir şey çıaramamalarının yanı sıra kendilerine ait ne bir felsefi doktrinler ne de sanat ve edebi eserleri vardır. Türkler ve Moğollardan sadece savaşmak ve fethetmek için organize olmuş halklar olarak bahseder. Genelleyici ve indirgemeci bir bakış açısı hâkimdir.

Türkler ve Moğollar Pers ve Çin uygarlıkları arasında aracı oldular. Öz varlıklarından kalıcı hiçbir şey çıkarmadılar. Kurdukları özgün toplumlar ne dehalarının türünü gösterecek kadar özümsenmiş bir felsefi doktrin, ne bir sanat eseri ne de edebi bir eser üretmedi. Savaştan doğmuş ve fethetmek için organize edilmiş bu halkların, komşu toplumların entelektüel birikimi içinde erimeleri yavaşça olmadı, ona derhal, adeta bir ganimete sahip olmak ister gibi, aceleyle sarıldılar. (Cahun 2006: 5)

Eski Türk tarihi araştırmalarının açısından önemli olan bu eserde, bahis mevzuu alanda uzun yıllar sürecek olan tartışmaları doğuran iddialara yer verilmiştir. Sonraki yıllarda, hatta günümüze kadar olan süreçte Türkiye' deki eski Türk tarihi araştırmacıları, Avrupalı tarihçilerin tezlerine cevap verme isteği ile eserler meydana getirmişlerdir. Uzun yıllar tartışlagelen meselelerden biri daha önce de belirtildiği üzere uygarlıktır. Tarihsel düşünüş ve metot olarak dönemin yapısıyla uyumlu olan iki yazar, Léon Cahun ile Mustafa Celaleddin Paşa'nın arasındaki fark, tutarlı bir tarihsel anlatı oluşturma noktasında ortaya çıkmaktadır. Cahun'a 
göre "savaştan doğmuş" Türk ve Moğol halkları ele geçirdikleri bölgelerde adeta misafir gibi yaşamışlardır. Bunun nedeni olarak yaşadıkları bölgelerin halklarını sindirmek için "fazla barbar", onlar tarafından sindirilebilmek için ise yetersiz olmalarıdır (Cahun 2006: 5). Türk halkının "fazla barbar" olduğu göz önüne alındığında, Türk tarihini açıklamaya çalışan model de dönem Avrupa tarihçilerinin tarih anlayışına uygun ve basit olmalıydı. Cahun, bu bakış açısı doğrultusunda "Türk ve Moğol toplumlarının kurdukları devletlerin tarihsel analizi diğer toplumların ve çok daha karmaşık yapıdaki çağdaş devletlerin analizinde bir işaret ve sık sık da basitleştirilmiş bir model olarak kullanılabilir." Demektedir (Cahun 2006: 5).

Bahsedilen iki yazarın eserlerinde yalnızca farklılıklar yoktur. İki eserde de din olgusunun vurgulanması dikkat çekicidir. Cahun, Türklerin ve Moğolların başarılarında dinî coşkunun hiç yeri olmadığını savunmaktadır. Irksal özelliklere dayalı bir açıklamaya girişir. Mustafa Celaleddin Paşa'nın eserinde de aynı durum görülür. Ancak o, eserinde Osmanlı Devleti'nin artık din misyonerliği yapmadığını, Osmanlı Devleti'nde yaşayan halkların da zaten antik çağda aynı ırka mensup olduğunu, bir ölçüde siyasi menfaat sağlayacağı umuduyla ifade etmiştir. Cahun ise tutarlılık içerisinde ele almak istediği tarihsel kurgusunda, Türklerin ve Moğolların doğuştan gelen zekâlarından dolayı medeniyet geliştiremediğini savunmaktadır. “Bu fatihler Perslerin ve Çinlilerin onlara öğrettiğini kendi yollarında ve doğuştan gelen zekâlarında geliştiremediler" şeklinde bir açıklama getirmektedir (Cahun 2006: 6). Din olgusunun hiç olmadığını savunmamakla birlikte kabul ettikleri dinin Türklere uygun olmadığını ima ederek şunları ifade etmiş̧tir:

Dini Düşünce Türklerde ve Moğollarda askeri ruhu yok edip, toplumlarını mistisizmin tembelliğinde zayıflatıp, zekâlarını dar bir yobaz kafası içine tıkarak, doğuştan gelen dürüstlüklerini yabani bir hoşgörüsüzlüğe saptırdığında imparatorlukları parçalandı ve bir halklar sürüsüne dönüştüler. Orta çağda çok canlı bir ulusçuluk duygusuna sahip olan halkları, olanca büyüklüklerine rağmen, yalnızca en fanatik ve dar milliyetçiliği kavradılar. Cengiz Han tarafından hayal edilen ve kurulan imparatorluk sonunda Buhara'nın küçük, yobaz, tiranlıkları, Hive ve Kokand kağanlıklarına dönüştü. (Cahun 2006: 6-7)

Medeniyet ve uygarlık konusuna dair son olarak Cahun'un olumlu görüşleri de belirtilmelidir. Cahun, Türklerin benimsedikleri Çin, İran ve Arap medeniyet ve sistemlerine katkı yaptıklarını da belirtir. Ona göre Türklerin hareket ve askeri dehası olmaksızın devasa Asya'da kendi siyasi sınırlarının dışına çıkamayacağı da bir gerçektir (Cahun 2006: 27). Dolayısıyla Türklerin sınırlı olan yanları sadece manevi etkileri olduğu görüşündedir.

Medeniyet dişında ikinci önemli husus Türk tarihinin ne zaman başladığı ve ilk Türk devletidir. Mustafa Celaleddin Paşa gibi Léon Cahun da antik çağ kaynaklarından bahseder. Strabon'un eserinde zikrettiği devletler, dağlar, nehirler ya da şehirler araştırıldığında şaşırtıcı sonuçlar elde edileceğini ifade eder. Ancak ırksal birlik fikrine karşı oluşuyla Mustafa Celaleddin Paşadan ayrılır. Mustafa Celaleddin Paşa eski çağda bir Türk İmparatorluğundan ve bu İmparatorluğun köken olarak hemen hemen homojen oluşundan bahsetse de, Léon Cahun'a göre "Moğol, Fin-Ogur, Altay, Turan ırkı ifadeleri bu hızlı bir şekilde kurulup yine hızlı bir şekilde dağılan toplumlar ve imparatorluklar kargaşasında, hayali gruplardan başka bir şey ifade etmez" (Cahun 2006: 30). Türklerde ve Moğollarda ırka dayalı bir oluşumdan çok farklı unsurların siyasi birlikteliği olduğu görüşünü savunmaktadır. Karşılaştırılabilecek bir diğer husus ise dildir. Mustafa Celaleddin Paşa'nın aksine Léon Cahun, dillerin bir grupta toplanabileceğini ancak onları konuşan insanların bir ırk ya da doğal bir tür altında toplanamayacağını ifade eder (Cahun 2006: 30-31). Genelleyici bir tutumla, Türk, Tatar ve 
Moğollar ile ilgili ırk sorusunun anlamsız olduğunu, zaten bu sorunun da bir cevabı olmadığını savunmaktadır.

Léon Cahun en eski Türk devleti hususunda ise Hyung-nuları işaret eder. Çinlilerin uzun yıllardır Türkleri tanıdıklarını ve Kuzeyde yaşayan tüm göçebe halkları Hyung-nu olarak adlandırdıklarını belirten Cahun, hiçbir milliyet ya da etnik karakter belirtmeyen Türkçe ya da Moğolca bir anlamı olmayan Çince ve çok eski bir sözcük olduğunu savunur (Cahun 2006: 35). Türklerin kökeni, eski çağı, ilk devletleri konusunda oldukça etkili olacak tüm bu görüşler uzun yıllar tartışılmıştır. Mustafa Celaleddin Paşa'nın büyük bir titizlikle ele aldığı Hunlar konusunda Cahun, daha farklı yaklaşarak, Hunları Türklerin ilk devletleri olarak işaret eder. Ancak Türkiye'deki eski Türk tarihçilerinin daha sonraki yıllarda ifade ettiği anlamda bir ilk devlet algısı yoktur. Cahun, Türkleri bu devletin bir parçası olarak görmektedir. Özetle Cahun'a göre Türklerin Hyung-nu'lardan oldukları kesindir ancak bütün Hyung-nu'lar Türk değildir.

Çinliler Hoang-Ho nehrinin kuzeyinde yaşayan ve hemen hemen hepsi göçebe olan bu halkları toplu olarak Hyung-nu olarak adlandırmışlardır, tıpkı Yunanlıların Tuna'nın kuzeyindeki bölgenin batısında yaşayanlara Selt, doğusunda yaşayanlara İskit adını verdikleri gibi... (Cahun 2006: 35)

Eski Türk tarihi alanında en çok tartışlan bir diğer hususun temellerinin yine bu dönemde atıldığı görülmektedir. Bu husus Mustafa Celaleddin Paşa'nın da görüşlerini aktardığı Avrupa Hunlarının kökeni ile ilgilidir. Cahun'a göre Avrupa Hunlarının Hyung-nular ile aynı kökenden olup olmadığını konusunda kesin bir bilgi olmamakla birlikte bu boş bir tartışmadır. Hunların Türkler, Moğollar ve Mançular kadar Hyung-nu oldukları görüşündedir. Bu hususta son olarak, "Türklerin kökenini araştırmak için gidilmesi gereken yer Hyung-nu'lardır." ifadesini kullanır(Cahun 2006: 36). Bu konu Cumhuriyet döneminde Türkiye'deki eski Türk tarihi araştırmalarının en temel konularından birisi olmuştur. Dönemin milliyetçi Türk aydınları için de heyecan verici ve merak uyandırıcıdır. Eski Türk tarihi alanının neredeyse tüm temel meselelerinin temellerinin bu dönemde atıldığı söylenebilir. İleriki yıllarda terminoloji değişse de Mustafa Celaleddin Paşa'nın ortaya koyduğu gibi yeni tezler ortaya koymakta zorluk çekilmiştir. Yeni kurulan ulus-devlet, Türkiye Cumhuriyeti'nin ilk dönemleriyle birlikte hassasiyetler daha da artmıştır. Türk Tarih Tezi gibi adımlar atılsa da başarılı olmamıştır. Türkiye'deki eski Türk tarihçilerinin büyük bir kısmı, Avrupalı tarihçilerin tezlerine karşı savunma konumunda kalmışlardır. Dolayısıyla Mustafa Celaleddin Paşa ve Léon Cahun ilk dönemde yaşanan kırılmayı yansıtmaktadırlar.

\section{Sonuç}

Eski Türk tarihi araştırmaları Avrupa'da kendi içeresinde tutarlı, bir takım temel kavramlar üzerinden ilerlemiş ve bu alanın tarihyazımı yıllar içerisinde dramatik değişimlere uğramamıştır. Yalnızca dünya tarihini tutarlı bir biçimde açıklamada yetersiz kalınması sonucu yeni çözümler üretildiğinde, ortaya konulan tezler bu doğrultuda değişmiştir. Türkiye'de ise eski Türk tarihçiliği yıllar içerinde değişim geçirmiş ve Avrupa'da ortaya konulan tezlere cevap niteliğinde eserler meydana getirilmiştir. Bir diğer husus ise eski Türk tarihi içerisindeki birçok temek meselenin bu zıtlık üzerinden doğmasıdır. Mustafa Celaleddin Paşa ve Leon Cahun bahsedilen sürecin ilk somut örneklerini oluşturmaktadır. Yaptıkları açıklamalarla bu alanın günümüzde kabul gören ancak nasıl bir süreçten sonra ve neden kabul gördüğü üzerinde fazla durulmamış olan birçok meselesinin temellerini atmışlardır. Türklerin uygarlığa katkıları, medeniyetleri, kökenleri ve ilk devletleri gibi pek çok mesele üzerinde asgari müştereğin oluşmaya başlaması bu döneme rastlar. Günümüzde Türkiye'de yayımlanan eski Türk tarihi 
eserlerinde genellikle Türk tarihi Hyung-nular ile başlatılmaktadır. Avrupa Hunları da bu devletin devamı sayılmaktadır. Hatta bu devamlılığı vurgulamak için Asya Hunları ifadesi kullanılmaya başlanmıştır. Bunun gibi birçok husus günümüzde neredeyse tartışmasız olarak kabul görmektedir. Ancak tüm bu hususlar, eski Türk tarihi araştırmalarının her döneminde aynı olmamıştır. Farklılıklar iç ve dış etkenlere göre değişmektedir. Her dönemde hassasiyet ve itki noktalarına göre tartışma konuları ortaya çıkmış, bazı meseleler ise yıllarca çözüme kavuşturulamadan tartı̧̧lagelmiştir.

Bu bağlamda, Mustafa Celaleddin Paşa ve Léon Cahun Türkiye'deki eski Türk tarihçiliğinin izlediği yönün başlangıç aşamasını yansıtır. Günümüzde eski Türk tarihçiliğinin birçok konusunun ve tartışmalı hususlarının temellerini attıkları görülmektedir. Dönem tarihçiliğinin eğilimlerini takip etmişler ve buluntuların oldukça az olduğu bir dönemde, Türk tarihinin eski çağı ile ilgili görüşlerini aktarmışlardır. Ancak iki yazarın aktardığı görüşler birbirinden oldukça farklıdır. Mustafa Celaleddin Paşa, siyasi durumun etkisiyle, Türklerin uygarlığa katkıları, medeniyetleri gibi hususlarda dikkatli ve titiz davranmıştır. Bu nedenle Avrupa Hunlarını dahi Türk tarihinden dışlamıştır. Moğollar ile Türkler arasında net bir ayrım olduğunu da vurgulamak istemiştir. Rumeli bölgesinde en eski Türk topluluklarının yaşadığını dilsel verilerle kanıtlamaya çalışmıştır. Tüm bunlar dönem tarihçiliğinin etkileri ile beyan edilmiş görüşlerdir. Ayrıca iç etken olarak Osmanlı Devleti'nin zor durumda bulunmasının da etkisi vardır. Bu nedenle ırka dayalı bir model oluşturmakta ve yaşadığı dönem için Hristiyan topluluklara bu yönde çağrı yapmaktadır. Léon Cahun ise hem medeniyet hem ilk Türk toplulukları ve devletleri ile ilgili farklı görüşlere sahiptir. Moğollar ve Türkler arasında ayrım yapmamış, bu toplulukların medeniyet oluşturamayacak kadar barbar olduklarını belirtmiştir. İlk Türk devleti olarak ise Hyung-nuları işaret eder. Ancak bu konuda Mustafa Celaleddin Paşanın aksine heterojen bir yapı olduğunu ima etmiştir. Cahun'un görüşlerinin siyasi altyapısı olmakla birlikte, kendisini asıl etkileyen, daha önce de belirtildiği üzere dönem Avrupa tarihçilerinin seküler ve tutarlı bir tarihsel anlatı oluşturma girişimleri olmuştur.

Günümüze dek eski Türk tarihi alanında Mustafa Celaleddin Paşa'nın adı, Léon Cahun'a göre çok daha az zikredilmiştir. Türkiye'deki milliyetçi aydınları ve eski Türk tarihi araştırmalarını etkilese de ortaya attığı iddialar ve savunduğu tezler bazı eserlerin giriş bölümlerinde tekrar edilmekten öteye gidememiştir. Cahun'un eseri ise çok daha fazla adından söz ettirmiştir. Guignes'den sonra belki de en çok tartışılan ve dikkat çeken isim olmuştur. Bunun nedenlerinden biri Cahun'un tarihi romanlarının büyük yankı uyandırması ve tanınmasında etkili olmasıdır. Cahun'un daha sık zikredilmesindeki bir diğer neden, Türkiye'de Cahun'un ve dönemin diğer Avrupalı eski Türk tarihçilerinin bazı tezlerine cevap verme ihtiyacının hissedilmesidir. Ancak bu durum eski Türk tarihinin neredeyse bütün temel meselelerinin oluşumunda Avrupalı tarihçilerin etkili olması sonucunu doğurmuştur. Avrupalı tarihçilerin tezlerine cevap verilerek, eski Türk tarihi ile ilgili önemli konularda asgari müşterek sağlanmıştır. Dolayısıyla, çalışmada ortaya konulmaya çalışıldığı üzere, ortaya atılan tezler üzerine yapılan tartışmaların dışına çıkılamamış ve Mustafa Celaleddin Paşa'nın yaptığı gibi yeni konular ve fikirler ortaya atılamamıştır. Eski Türk tarihi alanında Cumhuriyet döneminin başlarından itibaren, Türkiye'deki eski Türk tarihçilerinin büyük bir kısmı, Avrupalı tarihçilerin tezlerine karşı savunma konumunda kalmışlardır. 


\section{Kaynakça}

AÇIKGÖZ, Halil (2005), Cemil Meriç ile Sohbetler, İstanbul: Doğu Kütüphanesi.

AKÇURA, Yusuf (1978), Türkçülük: Türkçülü̈̆̈̈n Tarihî Gelişimi, İstanbul: Türk Kültür Yay.

BREGEL, Yuri (1988), “Barhold Vasili Vladimirovich", Encyclopedia Iranica, C III (8): 830-832.

BURY, J. B. (2015), A History of the Eastern Roman Empire, Londra: Cambridge University Press.

CAHUN, Léon (2006), Asya Tarihine Giriş Kökenlerden 1405'e Türkler ve Moğollar, İstanbul: Seç Yay.

CARR, Erward Hallett (2002), Tarih Nedir?, İstanbul: İletişim Yay.

Copeaux, Etienne (2006), Tarih Ders Kitaplarnda (1931-1993) Türk Tarih Tezinden Türk-Islam Sentezine, İstanbul: İletişim Yayınları.

ÇAPA, Mesut (2002, Mayıs-Kasım), "Cumhuriyetin İlk Yıllarında Tarih Öğretimi", Ankara Üniversitesi Türk Inkllap Tarihi Enstitüsü Atatürk Yolu Dergisi, (29-30): 39-55.

ERSANLI, Büşra (2015), İktidar ve Tarih Türkiye'de "Resmi Tarih" Tezinin Oluşumu (1929-1937), İstanbul: İletişim Yay.

FREITAG, Ulrike (1997), "The Critique of Orientalism", Companion to Historiography, Londra: Routledge.

GILYAZOV, İskander (2002), Tyurkizm i Stanovlenie i Razvite, Kazan: Kazanskiy Gosudarstvenny Universitet İnstitut Vostokvedeniya Fakultet Tatarskoy Filologii i İstorii.

GÜRSOY, Şahin - Çapçıŏlu, İlhan (2006), "Bir Türk Düşünürü Olarak Ziya Gökalp: Hayatı, Kişiliği ve Düşünce Yapısı Üzerine Bir İnceleme", Ankara Üniversitesi Illahiyat Fakültesi Dergisi, C 47 (2): 89-98.

IGGERS, Georg (2004), “20. Yüzyılda Tarih Yazımı”, Tarihin Kötüye Kullanımı, İstanbul: Tarih Vakfı Yurt Yayınları.

KANLIDERE, Ahmet (2004), "Sovyet ve Türk Tarih Yazıcllğıında Rusya Müslümanlarının Düşünce Tarihi", Türkiye Araştırmalar Literatür Dergisi, C II (1): 149-181.

KONOW, Sten (1927, Ekim), "Obituary Notices Vilhelm Thomsen”, Journal of Royal Asiatic Society of Great Britain \& Ireland, C 59(4): 929-934.

KÖPRÜLÜ, Mehmed Fuad (2008), Türkiye Tarihi: Anadolu İstilasina Kadar Türkler, Ankara: Akçağ Yay.

LATKA, Jerzy S. (1987), Lehistan'dan Gelen Şehit Mustafa Celaleddin Paşa/Konstanty Borzecki, İstanbul: Boyut Yay.

LAUFER, B. (1918), “Edouard Chavannes", Journal of the American Oriental Society, C. 38: 202-205.

Mustafa Celaleddin Paşa (2014), Eski ve Modern Türkler, İstanbul: Kaynak Yay.

ORTAYLI, İlber (2011), Tarih Yazıcllı Üzerine, Ankara: Cedit Neşriyat.

PALA, Ayhan (2012), "Türkiye'de Orta Asya Türk Tarihi Araştırmaları", Tarih ve Medeniyetler Tarihi Bildiriler V, Ankara, ss. 2457-2464.

PLiNiUS (1855), The Natural History of Pliny Vol.II, (çev. John Bostock, H. T. Riley), Londra: H. G. Bohn.

Pomponius Mela (1843), Géographie de Pomponius Mela, (çev. Louis Baudet), Paris: C. L. F. Panckoucke.

SINGER, Isidore - KAHN, Zadoc (1902), “Cahun, David Léon", The Jewish Encyclopedia, C.3, Londra: Funk and Wagnalls.

ÜSTEL Füsun (2004), Imparatorluktan Ulus-Devlete Türk Milliyetçiliği: Türk Ocaklarn (1912-1931), İstanbul: İletişim Yay.

WOOLF, Daniel (2005), "Historiography", New Dictionary of the History of Ideas Vol. 1, (ed. Marianne Horowitz), Gale: Thomson Gale.

YÜCE, Nuri (1979, "Gyula Nemeth Hayatı ve Eserleri”, İstanbul Üniversitesi Edebiyat Fakültesi Türk Dili ve Edebiyatı Dergisi, C. 23: 229-264. 